\title{
Determination of protein extraction and trypsin hydrolysis conditions for producing hydrolysates with antioxidant activity from perilla seed meal
}

\author{
Ja Min Kim, Kyung Young Yoon* \\ Department of Food and Nutrition, Yeungnam University, Gyeongsan 38541, Korea

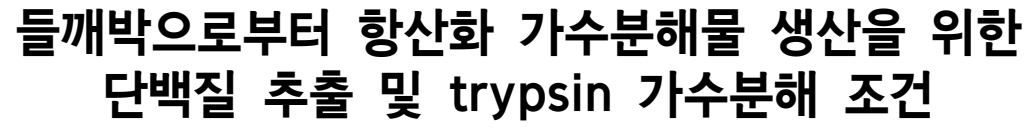 \\ 김자민 · 윤경영* \\ 영남대학교 식품영양학과
}

\begin{abstract}
Perilla seed meal (PSM) is an agricultural by-product that contains a lot of functional substances and protein, and is thus a functional food material. This study aimed to determine the optimal conditions of protein extraction and enzymatic hydrolysis required to produce hydrolysate with antioxidant activity from PSM. We determined the optimal conditions required to extract proteins from PSM by measuring the browning degree and protein content of extracts obtained at $\mathrm{pH} 5$ and of precipitates at $\mathrm{pH} 3$. The protein yield and content were high $(67.3 \%$ and $109.2 \mathrm{mg} / \mathrm{g}$, respectively), and the browning degree was low (1.00) after extraction at $\mathrm{pH} 10$ and precipitation at $\mathrm{pH} 4$. We hydrolyzed PSM protein with trypsin at various concentrations for different periods to establish the optimal hydrolysis conditions needed to produce PSM protein hydrolysates with antioxidant activity. The antioxidant activity was maximal in hydrolysates obtained by incubation for $3 \mathrm{~h}$ with 25 units of trypsin. Therefore, the optimal conditions required to extract protein from PSM comprised extraction at $\mathrm{pH} 10$, precipitation at $\mathrm{pH} \mathrm{4}$, and enzymatic hydrolysis with 25 units of trypsin for $3 \mathrm{~h}$.
\end{abstract}

Key words : perilla seed meal, agricultural by-product, protein extraction, antioxidant enzymatic hydrolysate

서 론

들깨(Perilla frutescens var. japonica Hara)는 꿀풀과에 속 하는 일년생 초본식물로 우리나라를 비롯한 베트남, 중국, 일 본 등 아시아 국가에서 널리 재배되고 있으며, 잎과 종실 모 두 쓰임새가 다양하다. 주로 들깨의 잎은 신선 잎채소로 이용 되고, 종자는 가루를 내어 양념으로 쓰거나 볶아서 기름을 착 유하여 조미용으로 사용된다(Park과 Yoon, 2018). 들깨 종자 에는 약 $40 \%$ 의 기름이 함유되어 있으며, 그 중 $\omega-3$ 계 고도불
포화지방산의 일종인 $\alpha$-linolenic acid가 $60 \%$ 이상을 차지하 고 있다(Longvah와 Deosthale, 1998; Yamamoto와 Ogawa, 2002). 그리고 들깨 종자 기름에는 linoleic acid, oleic acid와 같은 불포화지방산을 다량 함유하여 고혈압, 염증, 심혈관 및 자가 면역질환과 같은 다양한 질병을 예방한다고 밝혀지면서 들깨 기름의 소비량은 증가하고 있는 추세이다(Gang과 Kim, 1998; Kim 등, 2019; Park과 Yoon, 2018). 들깨박은 들깨 종 자를 착유하고 남은 농산가공부산물로써 단백질, 다당류, 페 놀물질, phytic acid 등 다양한 기능성 물질을 다량 함유하고

*Corresponding author. E-mail : yoonky2441@ynu.ac.kr, Phone : +82-53-810-2878, Fax : +82-53-810-4768

Received 01 June 2020; Revised 10 July 2020; Accepted 28 July 2020.

Copyright (c) The Korean Society of Food Preservation.

This is an Open Access article distributed under the terms of the Creative Commons Attribution Non-Commercial License (http://creativecommons.org/licenses/by-nc/4.0) which permits unrestricted non-commercial use, distribution, and reproduction in any medium, provided the original work is properly cited. 
있다(Zhu와 $\mathrm{Fu}, 2012)$. 특히 들깨박의 주성분은 단백질로 그 함량이 약 $36.3 \%$ 로 식물성 단백질 공급원으로 식품가공 분 야에서 사용할 수 있는 식품소재로써 높은 가치를 지니고 있 음에도 불구하고, 대부분이 사료로 사용되거나 폐기되고 있 다(Kim 등, 2019; Longvah와 Deosthale, 1998).

일반적으로 식품 단백질은 큰 분자량으로 인해 용해성, 기 포성, 유화성 등의 기능적 특성이 낮아 식품가공 적성이 떨어 지므로 효소분해에 의해 얻어진 단백질 가수분해물을 식품 소재로 많이 사용하고 있다. 식품단백질 가수분해물 제조를 위해서는 식품으로부터 단백질의 추출이 선행되어야 하며, 식품가공 분야에서는 식품으로부터 단백질 추출을 위해 주로 물리 · 화학적 방법 및 효소 추출법을 사용하고 있다(Jang과 Yoon, 2015). 그 중 알칼리 추출법은 효소적 방법이나 기타 물리 · 화학적 방법에 방법이 간단하며, 비용대비 추출효율이 높고 유해물질을 파괴시키는 등의 장점을 가지고 있어 식품 으로부터 단백질을 추출하는데 많이 사용되고 있지만(Jang과 Yoon, 2015; Kim 등, 2011; Kwon 등, 2006), 알칼리 추출 시 사용되는 추출용매 및 침전 $\mathrm{pH}$ 는 추출되는 단백질의 종류 와 양뿐만 아니라, 단백질의 기능성에 미치는 영향이 크므로 시료에 따라 단백질 추출조건을 확립하는 것이 매우 중요하 다(Bae와 Rhee, 1998; Jang과 Yoon, 2015).

단백질은 종류에 따라 특성이 다르므로 단백질을 변형시 켜 기능적 특성을 개선하여 식품에의 이용성을 증가시키려는 연구가 많이 시도되고 있다. Jang 등(2009)은 홍게 가공부산 물을 단백질 분해효소를 이용하여 가수분해하여 향미소재 및 반응향의 전구물질로서 가능성을 확인하였으며, Jang과 Yoon (2018)은 도로묵의 어육과 알로부터 가수분해물을 제조한 후 항염증 활성을 평가하여 항염증 펩타이드의 좋은 자원이라고 보고하였다. 단백질의 기능적 특성을 개선시키기 위한 방법 으로는 산이나 알칼리를 이용하여 단백질을 가수분해하는 화 학적 변형과 단백질에 효소를 처리하여 가수분해하는 효소적 변형이 있다. 화학적 변형방법은 유해물질의 생성과 필수 아 미노산의 손실 등의 문제점이 있으므로 주로 가수분해 효소 처리를 통해 단백질의 가공기능성을 향상시킨다(Lee 등, 1995; Noh 등, 2012; Rahama와 Rao, 1983). 펩타이드는 단 백질이 아미노산으로 분해되는 과정에서 생성되는 중간산물 로 효소적 가수분해에 의해 얻어진 펩타이드는 항산화 활성 을 비롯하여 항당뇨, 항고혈압, 항암 등의 다양한 생리활성에 관여한다고 보고되고 있다(Kim 등, 2019; Park과 Yoon, 2018). 뿐만 아니라 최적조건에서 제조된 효소적 가수분해물 은 고분자인 단백질보다 비교적 저분자인 펩타이드가 함유되 어 생체 내에서 쉽게 이용될 뿐만 아니라, 다양한 식품 및 가 공품에서의 이용성도 높다(Jang과 Yoon, 2015).

따라서 본 연구는 들깨박을 이용하여 항산화 활성을 갖는
효소분해물을 생산하고, 향후 기능성 식품소재로의 활용하기 위한 기초자료를 제공하고자 수행되었다. 이를 위해 들깨박 으로부터 효율적으로 단백질을 추출하기 위하여 알칼리 추출 용매 및 침전 $\mathrm{pH}$ 조건을 설정하였다. 즉, 들깨박을 여러 구간 의 추출용매 및 침전 $\mathrm{pH}$ 를 이용하여 단백질을 추출한 후 각 $\mathrm{pH}$ 에 따라 회수된 단백질의 양, 갈변도 및 추출효율을 분석 하여 알칼리 추출의 최적 $\mathrm{pH}$ 조건을 설정하였다. 또한, 설정 된 조건으로 추출한 들깨박 단백질로부터 항산화 효소분해물 을 생산하기 위하여 trypsin을 이용하여 농도 및 시간에 따른 효소분해물의 항산화 활성을 측정하여, $\operatorname{trypsin}$ 분해조건을 선정하고자 하였다.

\section{재료 및 방법}

\section{실험재료}

본 실험에 사용된 들깨박은 경기도 남양주시에서 2015년 도에 재배된 국내산 들깨를 냉압착 방식으로 들기름을 착유 하고 남은 부산물을 순수미기름집(Namyangju, Korea)으로 부터 제공받았다. 들깨박은 이물질을 제거하고 분쇄기로 분 쇄한 후 체질하여 $-40^{\circ} \mathrm{C}$ 에 보관하면서 시료로 사용하였으며, 들깨박의 수분, 조지방, 조회분, 조단백 및 탄수화물의 함량 은 각각 $5.67,16.46,5.24,32.27$ 및 $39.31 \%$ 이었다.

\section{들깨박 단백질의 알칼리 추출}

들깨박으로부터 단백질을 추출하기 위하여 Jang과 Yoon (2015)의 방법에 따라 알칼리 추출하였다. 즉, 들깨박 $5 \mathrm{~g}$ 에 $100 \mathrm{~mL}$ 의 증류수를 넣고 $25^{\circ} \mathrm{C}$ 에서 1 시간 교반시킨 후 $1 \mathrm{~N}$ $\mathrm{NaOH}$ 를 이용하여 $\mathrm{pH}$ 를 $8,9,10,11$ 및 12 로 조정하였다. 이 혼합물을 $25^{\circ} \mathrm{C}$ 에서 1 시간 교반 한 후 $1,600 \times g$ 에서 30 분 동안 원심분리(Supra-21K, Hanil, Incheon, Korea)하여 상등 액을 취하였다.

\section{알칼리 추출 단백질의 등전점 침전}

알칼리 추출법으로 얻은 들깨박 단백질 추출물에 함유된 단백질을 회수하고자 등전점 침전을 실시하였다. 즉, $1 \mathrm{~N} \mathrm{HCl}$ 을 이용하여 분획물의 $\mathrm{pH}$ 를 2,4 및 6 으로 조정한 후 $25^{\circ} \mathrm{C}$ 에 서 1 시간 동안 방치하여 단백질을 침전시켰다. 이 혼합물을 $1,600 \times g$ 에서 30 분간 원심분리하여 침전 단백질을 얻었으며, 침전 단백질은 중량대비 $1: 2(\mathrm{w} / \mathrm{v})$ 의 증류수를 가하여 수세하 고, 다시 원심분리를 통하여 단백질 추출물을 얻었다. 이후 단백질 추출물에 증류수를 가하여 homogenizer(AM-1, Nissei, Tokyo, Japan)로 균질화시킨 후, 단백질 수용액을 1 $\mathrm{N} \mathrm{NaOH}$ 를 이용하여 $\mathrm{pH}$ 7로 중화시킨 후 냉장보관하면서 사용하였다. 


\section{갈변도 측정}

알칼리 추출법에 의해 추출된 단백질의 추출용매 $\mathrm{pH}$ 에 따 른 갈변화 정도를 확인하기 위해 Song 등(1966)의 방법에 따 라 갈변도를 측정하였다. 각 시료 $100 \mu \mathrm{L}$ 에 단백질 응집으로 인한 파장의 산란을 최소화하기 위해 $16 \%(\mathrm{w} / \mathrm{v})$ sodium dodecyl sulfate(SDS)를 $20 \mu \mathrm{L}$ 첨가한 후 microplate(Epoch microplate spectrophotometer, BioTek, Winooski, VT, USA) 를 이용하여 $420 \mathrm{~nm}$ 흡광도를 측정하였다.

\section{단백질 함량 측정}

단백질 추출물에 함유된 가용성 단백질 함량은 Smith 등 (1985)의 bicinchoninic acid(BCA)법에 따라 bovine serum albumin(BSA)을 표준품으로 이용하여 작성한 표준곡선에 의하여 산출하였다. 즉, 시료 $20 \mu \mathrm{L}$ 에 $\mathrm{BCA}$ reagent(copper (II) sulfate pentahydrate $4 \%$ solution bicinchoninic acid solution $=1: 50, \mathrm{v} / \mathrm{v}) 160 \mu \mathrm{L}$ 를 혼합하여 $37^{\circ} \mathrm{C}$ 에서 30 분간 반응시킨 후, microplate(Epoch microplate spectrophotometer, BioTek)를 이용하여 $560 \mathrm{~nm}$ 에서 흡광도를 측정하였 다. 단백질 추출의 효율을 평가하기 위해 회수율을 측정하였 으며, 회수율은 알칼리 추출법으로 얻은 들깨박 단백질 추출 물에 함유된 단백질 함량에 대한 등전점 침전으로 얻은 단백 질 함량의 비율로 나타내었으며, 다음과 같이 계산하였다.

Recovery yield $(\%)=$

Protein content of residue obtained by precipitation extraction $(\mathrm{g})$

Protein content of extract obtained 100 by alkaline extraction $(\mathrm{g})$

들깨박 및 들깨박 단백질 추출물에 함유된 단백질의 함량을 비교하기 위하여 조단백 자동분석장치(Distillation Unit B-323, Buchi, Flawil, Switzerland)를 이용하여 micro-Kjeldahl법에 준 하여 조단백질의 함량을 측정하였다.

\section{들깨박 단백질 추출물의 최적 가수분해 조건 설정}

들깨박 단백질 추출물의 가수분해를 위한 최적 효소를 선 정하기 위하여 5 종의 단백질 분해효소, 즉 alcalase, neutrase, trypsin, papain 및 pepsin을 이용하여 효소반응 후 얻은 가수 분해물의 항산화 활성을 측정하였으며, 그 결과 trypsin 가수 분해물의 항산화 활성이 가장 높은 것으로 측정되었다. 따라 서 알칼리 추출 및 등전점 침전을 이용하여 얻은 들깨박 단백 질 추출물의 trypsin 효소분해물을 제조하고자 하였으며, 이 를 위해 효소농도 및 반응시간에 따른 항산화활성을 측정하 였다. 먼저 최적의 효소 농도를 설정하기 위해 들깨박 단백질
추출물을 $0.1 \mathrm{M}$ sodium phosphate buffer(pH 8)를 이용하여 $1: 20(\mathrm{w} / \mathrm{v})$ 농도로 제조하였다. 이후 trypsin을 $5,10,15,20$, 25 및 30 unit 농도로 첨가하여 $37^{\circ} \mathrm{C}$ 에서 1 시간 동안 가수분 해하였다. 그 후 $100^{\circ} \mathrm{C}$ 에서 5 분간 가열하여 효소반응을 정지 시키고, $1,600 \times g$ 으로 원심분리하여 얻은 상등액의 항산화 활성을 측정하였다.

최적의 가수분해 시간을 설정하기 위해 들깨박 단백질 추 출물을 $0.1 \mathrm{M}$ sodium phosphate buffer $(\mathrm{pH}$ 8)를 이용하여 $1: 20(\mathrm{w} / \mathrm{v})$ 농도로 제조한 후, trypsin 25 unit를 첨가하여 $37^{\circ} \mathrm{C}$ 에서 1-6시간 동안 가수분해하였다. 가수분해 후 $100^{\circ} \mathrm{C}$ 에서 5 분간 가열한 후 $1,600 \times g$ 으로 원심분리하여 얻은 상등액의 항산화 활성을 측정하였다.

\section{항산화 활성 측정}

$\mathrm{DPPH}$ (1,1-diphenyl-2-picryl-hydrazyl) 라디칼 소거활성은 $\mathrm{Kim}$ 등(2019)의 방법에 의하여 실험하였다. 시료 $100 \mu \mathrm{L}$ 에 $0.2 \mathrm{mM} \mathrm{DPPH}$ 용액 $50 \mu \mathrm{L}$ 를 가하여 30 분간 $37^{\circ} \mathrm{C}$ 에서 방치 한 다음 $517 \mathrm{~nm}$ 에서 microplate(Epoch, BioTek)를 이용하여 흡광도를 측정하였으며, DPPH radical scavenging activity $(\%)=100-[$ (absorbance of sample/absorbance of control) $\times 100]$ 에 의하여 활성도를 산출하였다.

ABTS(2,2'-azino-bis(3-ethylbenzothiazoline-6-sulfonic acid) 라디칼 소거활성은 Kim 등(2019)의 방법에 의하여 실 험하였다. $7 \mathrm{mM} \mathrm{ABTS}$ 와 $2.45 \mathrm{mM}$ potassium persulfate를 증류수에 용해하고 암소에서 12-16시간 방치한 후, $80 \%$ 에 탄올을 이용하여 $734 \mathrm{~nm}$ 에서 $0.60 \pm 0.02$ 가 되도록 희석하였다. 시료 $50 \mu \mathrm{L}$ 와 희석된 $\mathrm{ABTS}$ 용액 $50 \mu \mathrm{L}$ 를 섞은 후 실온, 암소 에서 6 분간 반응시킨 후 $734 \mathrm{~nm}$ 에서 흡광도를 측정하였으며, ABTS radical scavenging activity $(\%)=100$ - [(absorbance of sample/absorbance of control $\times 100]$ 에 의하여 활성도를 산출하였다.

금속이온 킬레이팅 활성은 Park과 Yoon(2016)의 방법을 변형하여 측정하였다. 시료 $200 \mu \mathrm{L}$ 에 $2 \mathrm{mM} \mathrm{FeCl}_{2}$ 와 $5 \mathrm{mM}$ Ferrozine[3-(2-pyridyl)-5,6-diphenyl-1,2,4-triazine-4',4"-disu lfonic acid sodium salt]을 각각 $20 \mu \mathrm{L}$ 를 첨가하여 혼합하였 다. 이 혼합물을 실온에서 10 분간 반응시킨 후 $562 \mathrm{~nm}$ 에서 흡광도를 측정하였으며, metal-ion chelating activity $(\%)=$ 100 - [(absorbance of sample/absorbance of control $) \times 100]$ 에 의하여 활성도를 산출하였다.

\section{가수분해도 측정}

들깨박 단백질 효소분해물의 가수분해도를 측정하기 위해 Hoyle와 Merritt(1994)의 방법을 약간 변형하여 사용하였다. 즉, 효소분해물에 $20 \%$ trichloroacetic acid(TCA)를 동량 첨 
가하여 $10 \% \mathrm{TCA}$ 가용성 단백질을 얻은 후 이를 원심 분리 한 다음 상등액을 일정량 취하여 BCA법(Smith 등, 1985)에 따라 가수분해도를 측정하였다. 가수분해도는 총 단백질 함 량에 대한 TCA 가용성 단백질의 비율로 산출하였다.

\section{통계처리}

본 실험결과의 통계분석은 $\operatorname{SPSS}(25$, Chicago, IL, USA) 통계 프로그램을 이용하여 각 시험군 간의 $\mathrm{p}<0.05$ 수준에서 유의적인 차이를 one-way ANOVA로 분석하여 Duncan's multiple range test를 실시하거나 t-test를 실시하여 $\mathrm{p}<0.001$ 수준에서 유의성을 검증하였다.

\section{결과 및 고찰}

\section{알칼리 용출 $\mathrm{pH}$ 가 단백질 추출에 미치는 영향}

들깨박의 단백질 추출을 위해 용매 $\mathrm{pH} 8,9,10,11$ 및 12 에서 단백질을 용출하고, 추출용매의 $\mathrm{pH}$ 에 따른 단백질 함량 및 갈변도를 측정한 결과는 Fig. 1과 같다. 추출용매 $\mathrm{pH} 8$, $9,10,11$ 및 12 에서 단백질 함량이 각각 $84.1,115.6,154.7$, 166.9 및 $225.8 \mathrm{mg} / \mathrm{g}$ 으로 $\mathrm{pH}$ 가 증가할수록 단백질 용출량이

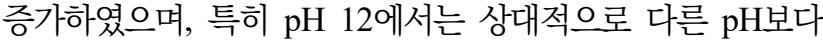
단백질 용출량이 급격하게 증가하였다. 이러한 결과는 Jang 과 Yoon(2015)이 추출 $\mathrm{pH}$ 에 따른 천마의 단백질 함량을 측 정한 결과, $\mathrm{pH}$ 가 증가함에 따라 단백질 추출량이 점차 증가 한다고 보고한 연구결과와 유사하였다. 또한, 미강의 용매 $\mathrm{pH}$ 에 따른 단백질의 함량을 측정한 결과, $\mathrm{pH}$ 가 증가할수록 상대적으로 단백질의 용출량이 증가한다는 연구결과 $(\mathrm{Kim}$

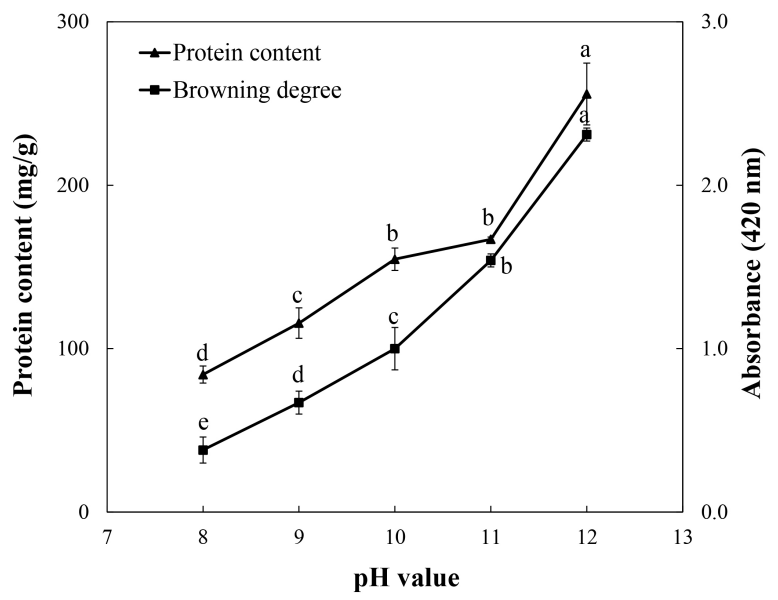

Fig. 1. Protein content and browning degree of the extracts obtained at different $\mathrm{pH}$ values.

Each value represents the mean $\pm \mathrm{SD}(\mathrm{n}=3)$. Values with different letters are significantly different using a one-way ANOVA $(\mathrm{p}<0.05)$.
등, 2011)와도 유사하였다. 단백질의 갈변도는 용매 $\mathrm{pH}$ 가 증 가함에 따라 유의적으로 증가하였으며, 특히 $\mathrm{pH} 11$ 과 $\mathrm{pH} 12$ 에서는 각각 1.54 및 2.31로 매우 높은 갈변도를 나타내었다. 알칼리법에 의한 단백질 추출 시 용매 $\mathrm{pH}$ 는 추출 단백질의 특성과 추출 효율에 많은 영향을 미친다. 높은 알칼리 조건은 포도당 및 과당과 같은 당류와 필수 아미노산 중의 하나인 lysine이 결합하여 glycosylamine 생성반응이 촉진되어 비효 소적 갈변반응이 증가되며, 이때 lysine은 구조적으로 glycolysine으로 변형되어 단백질의 흡수율 및 체내이용률이 감 소된다(Jang과 Yoon, 2015; Kim 등, 2011). 뿐만 아니라 단 백질 추출 시 높은 알칼리 조건은 lysinoalanine과 같은 잠재 독소물질을 생성시킬 수 있으며, 섬유질과 같은 다른 성분도 함께 용출되어 단백질의 영양성 및 품질을 저하시킨다(Wang 등, 1999). Jang과 Yoon(2015)은 탈지 천마 단백질 용출을 위해 단백질 함량과 갈변정도를 고려하여 $\mathrm{pH}$ 9로 선정하였 으며, Seo 등(2019)은 갈색거저리 유충 단백질의 알칼리 용 출 $\mathrm{pH}$ 는 갈변화가 본격적으로 증가하기 이전 구간인 $\mathrm{pH}$ 9로 선정하였다. 뿐만 아니라 $\operatorname{Kim}$ 등(2011)은 미강 단백질 알칼 리 용출 $\mathrm{pH}$ 를 갈변화가 증가하기 이전 구간인 $\mathrm{pH} 10$ 으로 보 고하였다. 따라서 단백질 함량과 갈변정도를 고려하여 $\mathrm{pH} 10$ 을 들깨박 단백질의 알칼리 용출 $\mathrm{pH}$ 로 결정하였다.

\section{침전 $\mathrm{pH}$ 가 단백질 함량 및 회수율에 미치는 영향}

다양한 알칼리 조건에서 얻은 단백질 분획을 $\mathrm{pH} 2,4$ 및 6 으로 조정하여 단백질을 침전시켰으며, 침전물과 상등액에 잔존하는 단백질의 함량을 측정한 결과는 Fig. 2 와 같다. $\mathrm{pH}$ 8 에서 추출된 단백질을 제외한 모든 시료에서 $\mathrm{pH} 4$ 에서 침

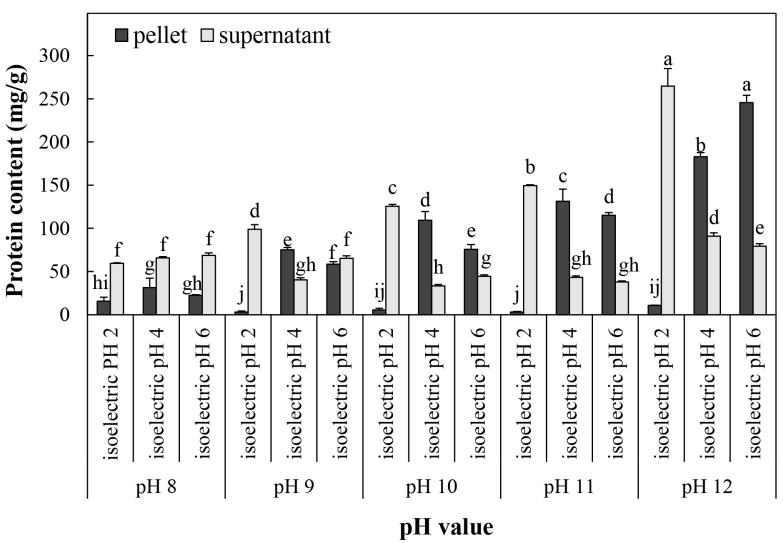

Fig. 2. Comparison of the amounts of precipitated protein and remaining soluble protein after isoelectric precipitation step at different $\mathbf{p H}$.

Each value represents the mean $\pm S D(n=3)$. Values with different letters are significantly different using a one-way ANOVA $(p<0.05)$. 
전시킨 침전물의 단백질 함량이 상등액에 남아있는 단백질 함량보다 높았으며, 특히 $\mathrm{pH} 10$ 에서 용출된 단백질을 $\mathrm{pH} 4$ 로 침전시킨 침전물의 단백질 함량 $(109.2 \mathrm{mg} / \mathrm{g})$ 이 상등액에 남아있는 단백질 함량 $(33.3 \mathrm{mg} / \mathrm{g})$ 보다 3.28 배 높게 나타났다. 들깨박 단백질의 추출용매 및 침전 $\mathrm{pH}$ 에 따른 단백질 회수율 을 나타낸 결과(Fig. 3), 추출 용매 $\mathrm{pH} \mathrm{8,9}$ 및 10 의 경우 침 전 $\mathrm{pH}$ 4일 때 각각 $37.2,79.8$ 및 $67.34 \%$ 로 가장 많은 단백질 을 회수할 수 있었으며, 반면 추출용매 $\mathrm{pH} 11$ 및 12 의 경우 침전 $\mathrm{pH}$ 6일 때 64.2\% 및 96.0\%로 높은 단백질 회수율을 보였다. 단백질은 구성하는 아미노산의 전기적 성질에 따라 등전점이 다르며, 들깨와 같은 식물 종자 단백질의 등전점은 $\mathrm{pH}$ 4-5 범위이다(Zhang 등, 2009). 단백질은 등전점일 때 낮 은 소수성으로 용해도가 최저가 되며 침전이 가장 많이 일어 난다(Wang 등, 1999). 들깨 단백질의 주요 아미노산은 aspartic acid, glutamic acid로 알려져 있으며, 이들 아미노산 의 등전점은 각각 $\mathrm{pH} 2.77, \mathrm{pH} 3.22$ 이므로 $\mathrm{pH}$ 3-4에서 용해도 가 최저가 되고 단백질 침전이 가장 많이 일어난다(Longvah와 Deosthale, 1998). 본 연구에서도 들깨박 단백질의 회수율이 대부분의 경우 침전 $\mathrm{pH}$ 가 4 일 때 가장 높은 것으로 확인되어 등전점 침전이 잘 일어났음을 알 수 있었다. 추출용매 $\mathrm{pH} 12$, 침전 $\mathrm{pH}$ 6에서 단백질의 회수율은 가장 높았으나, 갈변도가 매우 높게 측정되어(Fig. 1), lysine을 비롯한 필수아미노산의 amino-carbonyl 반응에 의한 glycosylamine 생성으로 단백질 이 열화되고 체내 이용성이 저하될 것으로 추측된다(Ajandouz 등, 2001; Seo 등, 2019), 또한 추출용매 $\mathrm{pH}$ 9, 침전 $\mathrm{pH}$ 4에 서의 단백질 회수율도 $79.83 \%$ 로 높았으나(Fig. 3), 실제 추출 된 단백질 함량은 $75.2 \mathrm{mg} / \mathrm{g}$ 으로 낮게 측정되었다(Fig. 2). 따라서 단백질 함량 및 갈변도 등을 고려하여 추출용매 $\mathrm{pH}$ 10 과 침전 $\mathrm{pH}$ 4를 단백질 추출을 조건으로 결정하였으며, 이



Fig. 3. Recovery yield of protein at different combinations of extraction $\mathrm{pH}$ and precipitation $\mathrm{pH}$.

Each value represents the mean $\pm \mathrm{SD}(\mathrm{n}=3)$. Values with different letters are significantly different using a one-way ANOVA $(\mathrm{p}<0.05)$.
때 단백질의 함량과 회수율은 각각 $109.2 \mathrm{mg} / \mathrm{g}$ 과 $67.3 \%$ 로 나타났다.

알칼리 추출 및 등전점 추출을 이용하여 얻은 들깨박 단백 질의 추출효율을 비교하기 위하여 건조물 중량에 대한 들깨 박과 들깨박 단백질의 조단백 함량을 측정하였으며, 그 결과 는 Fig. 4와 같다. 들깨박과 들깨박 단백질 추출물에 함유된 조단백질의 함량은 각각 $34.21 \%$ 와 $90.97 \%$ 로 측정되어 들 깨박 단백질 추출물의 단백질 함량이 들깨박에 비해 약 2.7 배 높았다. 따라서 선정된 알칼리 추출조건은 들깨박으로부 터 단백질을 추출하는데 매우 효율적인 것을 확인할 수 있 었다.

\section{항산화 들깨박 단백질 효소분해물 생산을 위한 효소농도 선정}

일반적으로 효소처리를 통해 얻어지는 효소분해물의 생리 활성은 효소농도, 반응시간 등과 같은 여러 변수에 의해 영향 을 받는다. 따라서 들깨박 단백질로부터 항산화 효소분해물 을 얻기 위한 최적 효소농도를 설정하기 위해 다양한 농도의 trypsin을 첨가하여 최적 $\mathrm{pH}(\mathrm{pH} 8)$ 및 최적온도 $\left(37^{\circ} \mathrm{C}\right)$ 에서 가수분해 후 각각의 분해물의 항산화 활성을 확인하였으며, 그 결과는 Fig. $5 \mathrm{~A}$ 에 나타내었다. $\mathrm{DPPH}$ 라디칼 소거능은 trypsin 농도 $0,5,10,15,20,25$ 및 30 unit에서 각각 17.51 , $55.31,60.81,63.43,61.38,64.45$ 및 44.19\%로 나타나, trypsin 처리에 의해 활성이 유의적으로 증가하였으며, 25 unit 농도의 효소를 첨가하였을 때에 가장 높은 소거활성을 보였다. ABTS 라디칼 소거능은 효소 처리에 의해 활성이 유 의적으로 증가하여 모든 효소농도에서 $60 \%$ 이상의 활성을 보였으며, 특히 효소농도 25 unit일 때 $85.53 \%$ 로 가장 높은 활성을 보였다. 금속이온 킬레이팅 활성은 25 unit 농도의

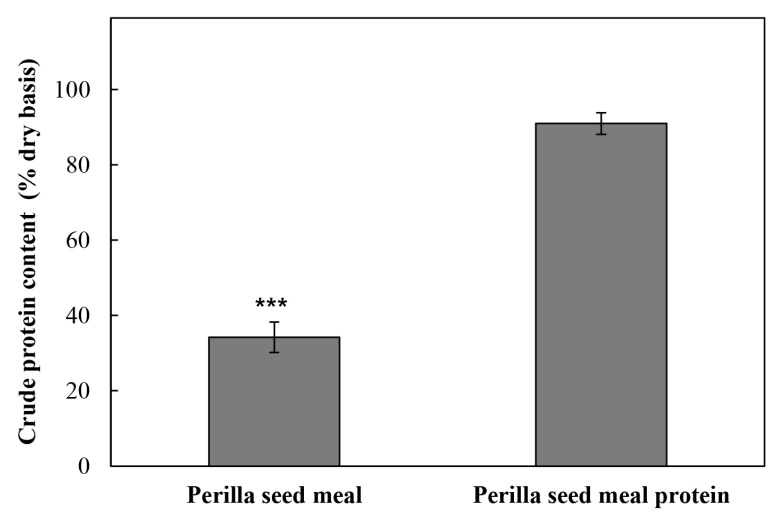

Fig. 4. Crude protein content of perilla seed meal and perilla seed meal protein extract.

Each value represents the mean $\pm \mathrm{SD}(\mathrm{n}=3) .{ }^{* * *} \mathrm{p}<0.001$ was considered significant using a t-test. 
(A)

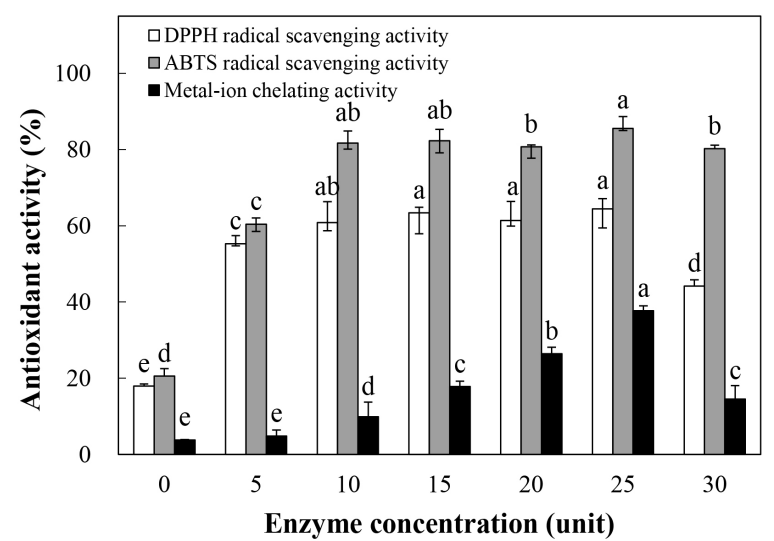

(B)

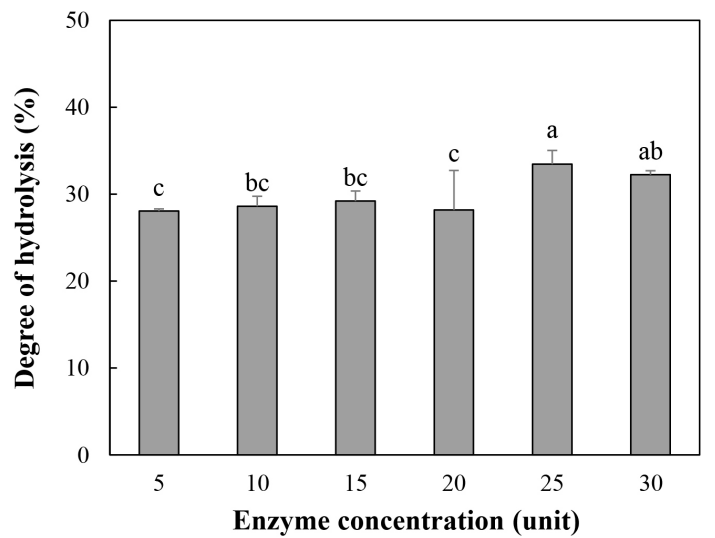

Fig. 5. Antioxidant activity (A) and degree of hydrolysis (B) of perilla seed meal protein hydrolysates obtained by trypsin at different enzyme concentrations.

DPPH radical scavenging activity (\%) and metal-ion chelating activity (\%) were tested 100 times diluted hydrolysate as sample. ABTS radical scavenging activity (\%) was tested 200 times diluted hydrolysate as sample. Values with different letters are significantly different at $p<0.05$ using a one-way ANOVA. Each value represents the mean $\pm \mathrm{SD}(\mathrm{n}=3)$.

trypsin을 첨가하여 얻은 효소분해물이 $37.71 \%$ 로 가장 높았 으며, 이는 trypsin 무처리군에 비해 약 10 배의 높은 활성을 나타내었다. 또한, 효소농도가 높아질수록 금속이온 킬레이 팅 활성이 증가하는 경향을 보였으나, 효소농도 30 unit에서 는 다시 감소하였다. 이상의 결과에서 효소농도가 25 unit에 서 얻은 들깨박 단백질 효소분해물이 유의적으로 가장 높은 항산화 활성을 가지는 것을 확인할 수 있었다.

다양한 효소농도로 가수분해된 혼합물의 가수분해도를 측 정하였으며, 그 결과를 Fig. $5 \mathrm{~B}$ 에 나타내었다. 효소분해물의 가수분해도는 $28.07 \%$ 에서 $33.46 \%$ 범위로 측정되었으며, 25 unit 농도의 효소를 첨가하였을 때 분해도 $33.46 \%$ 로 가장 높 은 값을 나타내었다. 또한, 효소농도가 증가함에 따라 가수분 해도도 증가하였으나 30 unit의 효소농도에서는 분해도가 다 소 감소하였는데, 이는 효소가 반응할 수 있는 기질의 양이 부족하기 때문으로 판단된다. 이상의 결과, 항산화 펩타이드 생성을 위한 들깨박 단백질 효소분해물의 최적 효소농도는 25 unit으로 결정되었다.

\section{항산화 들깨박 단백질 효소분해물 생산을 위한 분해 시간 선정}

들깨박 단백질의 효소분해물의 가수분해 시간을 설정하고 자 이전 실험에서 결정된 최적 효소농도(25 unit)에서 들깨박 단백질의 효소분해물을 제조하였으며, 이를 1-6시간 동안 가 수분해하여 각 효소분해물의 항산화 활성과 가수분해도를 측 정하였다. 그 결과는 Fig. $6 \mathrm{~A}$ 에서 보는 바와 같이 모든 효소 분해물의 DPPH 라디칼 소거능은 56.25-69.96\%의 범위로 $50 \%$ 이상의 활성을 나타내었다. 5 시간 동안 가수분해된 들
깨박 단백질 효소분해물의 DPPH 라디칼 소거능이 가장 높 은 활성을 보였으나, 각 실험군 간의 유의적인 활성 차이는 없었다. 들깨박 단백질 효소분해물의 ABTS 라디칼 소거능 은 분해시간 3 시간까지 증가하였으나 다시 감소하여 3 시간 동안 가수분해된 효소분해물이 $87.52 \%$ 로 유의적으로 가장 높은 소거활성을 나타내었다. 반면 6시간 동안 가수분해된 들 깨박 단백질 효소분해물은 ABTS 라디칼 소거능은 $71.79 \%$ 로 가장 낮은 소거활성을 나타내었다. 금속이온 킬레이팅 활성 은 ABTS 라디칼 소거능과 유사한 경향을 나타내었다. 즉, 금 속이온 킬레이팅 활성은 가수분해 시간이 길어질수록 증가하 다가 5 시간 이후부터 감소하였다. 3 시간 동안 가수분해한 효 소분해물이 $55.97 \%$ 의 가장 높은 금속이온 킬레이팅 활성을 보였으며, 1 시간 가수분해한 효소분해물이 $41.1 \%$ 의 금속이 온 킬레이팅 활성으로 가장 낮았다. 따라서 3시간 동안 가수 분해한 들깨박 단백질 효소분해물이 DPPH 라디칼을 제외한 모든 항산화 활성에서 높게 나타났다.

들깨박 단백질로부터 항산화 활성을 가진 효소분해물 생 산을 위한 최적 분해시간을 설정하기 위하여 1-6시간 동안 가 수분해된 혼합물의 가수분해도를 측정하였으며, 그 결과를 Fig. $6 \mathrm{~B}$ 에 나타내었다. 1시간에서 $31.16 \%$, 2시간에서 $32.58 \%$, 3 시간에서 $35.84 \%$, 4시간에서 $36.29 \%$, 5시간에서 $36.89 \%, 6$ 시간에서 $37.73 \%$ 의 가수분해도를 나타내어, 가수분해시간이 길어질수록 가수분해도도 증가하였다. Park과 Yoon(2018)의 연구에서는 들깨박을 flavourzyme를 이용하여 최적조건 $(\mathrm{pH}$ $7.0,50^{\circ} \mathrm{C}$, 효소농도 10 unit, 4시간)에서 가수분해한 분해물 의 가수분해도는 $69.16 \%$ 로 본 연구결과에서 확인된 가수분 해도보다 다소 높은 것을 확인하였다. 일반적으로 가수분해 
(A)

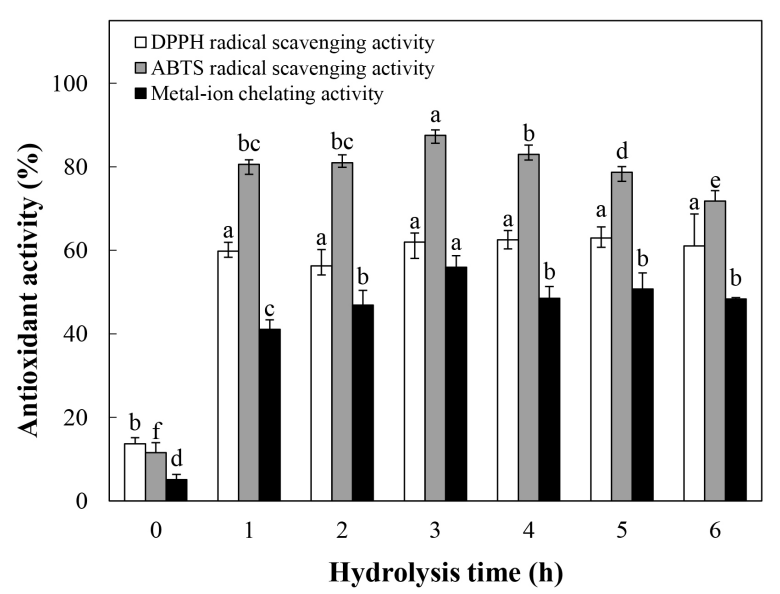

(B)

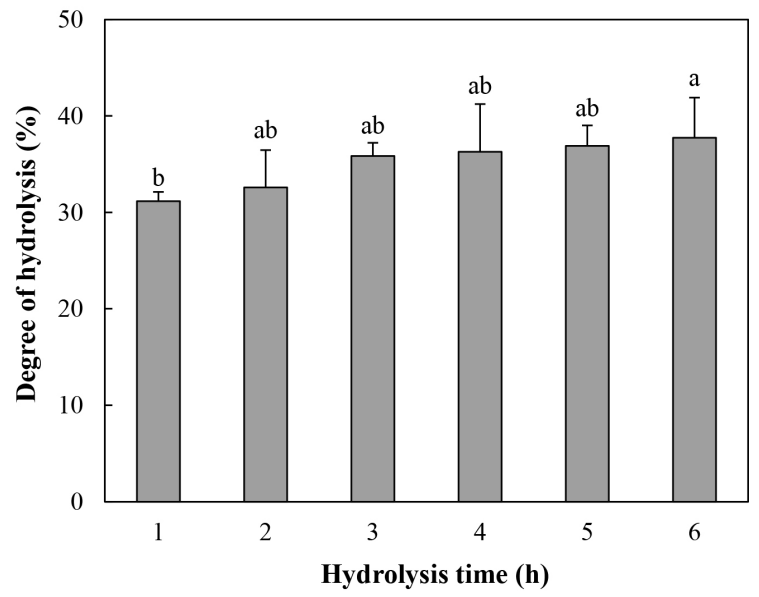

Fig. 6. Antioxidant activity (A) and degree of hydrolysis (B) of perilla seed meal protein hydrolysates obtained by trypsin at different hydrolysis times.

DPPH radical scavenging activity (\%) and metal-ion chelating activity (\%) were tested 100 times diluted hydrolysate as sample. ABTS radical scavenging activity (\%) was tested 200 times diluted hydrolysate as sample. Values with different letters are significantly different at $\mathrm{p}<0.05$ using a one-way ANOVA. Each value represents the mean \pm SD $(n=3)$.

도는 반응시간에 따라 달라지며, 반응시간이 증가함에 따라 가수분해도도 증가하는 경향을 보이지만, 가수분해도가 높은 것이 항산화 활성에 직접적인 영향을 주지는 않는다(Baek 등, 2019).

이상의 결과로 본 연구에서 얻은 항산화 들깨박 단백질 효 소분해물의 최적 가수분해 조건은 Table 1 과 같다. 즉, 들깨 박 단백질을 25 unit 농도의 trypsin을 첨가하여 3 시간동안 가 수분해하여 얻은 효소분해물이 가장 높은 항산화 활성을 보 였다. 또한, 최적의 가수분해 조건에서 얻은 들깨박 단백질 효소분해물의 DPPH 라디칼 소거능, ABTS 라디칼 소거능 및 금속이온 킬레이팅 효과는 각각 $61.97 \%, 87.52 \%$ 및 $55.97 \%$ 였으며, 이때의 가수분해도는 $35.84 \%$ 였다. Chen 등 (2012)은 호두 단백질 가수분해물로부터 항산화 펩타이드를 분리 및 정제하여 구조를 규명하였으며, Zhang 등(2011)은 병아리콩 단백질 가수분해물을 이용하여 새로운 항산화 펩타 이드를 분리하여 이의 아미노산 조성 및 서열을 규명하였다. 따라서 들깨박 단백질 효소분해물의 높은 항산화 활성으로
향후 항산화 펩타이드 생산을 위한 재료로써의 활용성이 클 것으로 판단된다.

\section{요 약}

본 연구에서는 농산가공부산물인 들깨박의 기능성 식품소 재로의 활용성을 증진시키기 위해 항산화 활성을 가진 단백 질 효소분해물을 생산하고자 하였다. 이를 위해 먼저 알칼리 추출법을 이용하여 들깨박으로부터 단백질을 추출하기 위해 용출 및 침전 $\mathrm{pH}$ 에 따른 단백질 함량과 갈변도를 측정하였 다. 용출 $\mathrm{pH}$ 가 증가함에 따라 단백질 함량과 갈변도가 증가 하였으며, $\mathrm{pH}$ 8에서 용출된 단백질을 제외한 모든 시료에서 침전 $\mathrm{pH}$ 4에서 침전된 단백질 함량이 상등액에 남아있는 단 백질 함량보다 높았다. 뿐만 아니라 단백질 회수율도 용출 $\mathrm{pH} 11$ 과 12 를 제외하고, 모두 침전 $\mathrm{pH}$ 4일 때 가장 높은 값 을 나타내었다. 따라서 갈변도와 단백질 함량을 고려한 들깨 박 단백질 추출을 위한 최적조건은 용출 $\mathrm{pH} 10$ 과 침전 $\mathrm{pH}$

Table 1. The optimal hydrolysis conditions for producing antioxidant hydrolysates from PSM protein

\begin{tabular}{|c|c|c|c|c|c|}
\hline \multicolumn{2}{|c|}{ Optimal conditions } & \multirow{2}{*}{$\begin{array}{c}\text { DPPH radical } \\
\text { scavenging activity }\end{array}$} & \multirow{2}{*}{$\begin{array}{c}\text { ABTS radical } \\
\text { scavenging activity } \\
(\%)\end{array}$} & \multirow{2}{*}{$\begin{array}{l}\text { Metal-ion chelating } \\
\text { activity } \\
(\%)\end{array}$} & \multirow{2}{*}{$\begin{array}{c}\text { Degree of hydrolysis } \\
(\%)\end{array}$} \\
\hline $\begin{array}{c}\text { Trypsin concentration } \\
\text { (unit) }\end{array}$ & $\begin{array}{l}\text { Hydrolysis time } \\
\text { (h) }\end{array}$ & & & & \\
\hline 25 & 3 & $61.97 \pm 2.2$ & $87.52 \pm 1.35$ & $55.97 \pm 2.73$ & $35.84 \pm 1.39$ \\
\hline
\end{tabular}

The results are revealed as Mean \pm SD of triplicates. DPPH radical scavenging activity (\%) and metal-ion chelating activity (\%) were tested 100 times diluted hydrolysate as sample. ABTS radical scavenging activity (\%) was tested 200 times diluted hydrolysate as sample. 
4로 결정되었으며, 선정된 최적조건에서 추출한 들깨박 단백 질 추출물의 조단백질 함량은 건물량 기준 $90.97 \%$ 로 측정되 었다. 들깨박으로부터 추출한 들깨박 단백질로부터 항산화 활성을 가진 효소분해물을 생산하기 위해 trypsin을 사용하여 효소분해물을 제조하였으며, 효소농도와 가수분해 시간에 따 른 항산화 활성과 가수분해도를 측정하였다. 그 결과, 들깨박 단백질 효소분해물의 최적조건은 효소 농도 25 unit, 가수분 해 시간 3 시간으로 확인되었으며, 최적 가수분해 조건에서 분해된 효소분해물의 DPPH 라디칼 소거능, ABTS 라디칼 소거능 및 금속이온 킬레이팅 활성은 각각 $61.97 \%, 87.52 \%$ 및 $55.97 \%$ 로 나타났다. 이를 통해 들깨박 단백질 효소분해물 은 높은 항산화 활성을 가지는 것으로 확인되었으며, 기능성 단백질 소재로의 활용뿐만 아니라, 항산화 펩타이드를 생산 을 위한 소재로의 활용가능성이 매우 높을 것으로 판단된다.

\section{Conflict of interests}

The authors declare no potential conflict of interest.

\section{ORCID}

Ja Min Kim https://orcid.org/0000-0002-2565-6087 Kyung Young Yoon

https://orcid.org/0000-0003-0626-5563

\section{References}

Ajandouz EH, Tchiakpe LS, Ore FD, Benajiba A, Puigserver A. Effect of $\mathrm{pH}$ on carmelization and Maillard reaction kinetics in fructose-lysine model system. J Food Sci, 66, 926-931 (2001)

Bae $\mathrm{SH}$, Rhee C. Influences of extraction $\mathrm{pH}$ on the functionality of soybean protein isolate. Korean J Food Sci Technol, 30, 557-561 (1998)

Baek D, Kim I, Jeong Y. Antioxidant and ACE inhibitory activities of Japanese Spanish mackerel (Scomberomorus niphonius) hydrolysates. J Korean Soc Food Sci Nutr, 48, 56-63 (2019)

Chen N, Yang H, Sun Y, Niu J, Liu S. Purification and identification of antioxidant peptide from walnut (Juglans regia L.) protein hydrolysates. Peptides, 38, 344-349 (2012)

Gang HJ, Kim JS. Bioactive of perilla. Food Industry and Nutrition, 3, 65-72 (1998)
Hoyle NT, Merritt J. Quality of fish protein hydrolysates from herring (Clupea harengus). J Food Sci, 59, 76-79 (1994)

Jang HL, Yoon KY. Optimized $\mathrm{pH}$ condition of protein extraction of Gastrodia elata Blume by alkaline method. Korean J Food Preserv, 22, 256-260 (2015)

Jang HL, Yoon KY. Optimal conditions of enzymatic hydrolysis for producing anti-inflammatory peptides from sandfish (Arctoscopus japonicus) hydrolysate. Korean J Food Sci Technol, 50, 203-208 (2018)

Jang JT, Seo WH, Baek HH. Enzymatic hydrolysis optimization of a snow crab processing by-product. Korean $\mathrm{J}$ Food Sci Technol, 41, 622-627 (2009)

Kim JM, Liceaga AM, Yoon KY. Purification and identification of an antioxidant peptide from perilla seed (Perilla frutescens) meal protein hydrolysate. Food Sci Nutr, 7, 1645-1655 (2019)

Kim W, Jung SY, Hong KW. Optimum pH condition of defatted rice protein extraction by alkaline method. Food Eng Prog, 15, 143-147 (2011)

Kwon HJ, Lee KH, Kim JH. Chun SS, Cho YJ, Cha WS. Effect of protease on the extraction and properties of the protein from silkworm pupa. J Korean Soc Appl Biol Chem, 49, 304-308 (2006)

Lee SH, Cho YJ, Kim S, Ahn BJ, Choi C. Optimal conditions for the enzymatic hydrolysis of isolated sesame meal protein. J Korean Soc Appl Biol Chem, 38, 248-253 (1995)

Longvah T, Deosthale YG. Effect of dehulling, cooking and roasting on the protein quality of Perilla frutescens seed. Food Chem, 63, 519-523 (1998)

Noh KH, Min KH, Seo BY, Kim SH, Seo YW, Song YS. Characteristics of protein from red crab (Chionoecetes japonicus) shell by commercial proteases. Korean $\mathrm{J}$ Nutr, 45, 429-436 (2012)

Park BY, Yoon KY. Conditions for hydrolysis of perilla seed meal protein for producing hydrolysates and ultrafiltered peptides and their antioxidant activity. Korean J Food Preserv, 25, 605-612 (2018)

Park JY, Yoon KY. Evaluation of antioxidant, $\alpha$-glucosidase inhibition and acetylcholinesterase inhibition activities of Allium hookeri root grown in Korea and Myanmar. Korean J Food Preserv, 23, 239-245 (2016)

Rahma EH, Rao MSN. Effect of acetylation and succinylation 
of cottonseed flour on its functional properties. J Agric Food Chem, 31, 352-355 (1983)

Seo M, Lee HJ, Lee JH, Baek M, Kim IW, Kim SY, Hwang JS, Kim MA. A study of the anti-inflammatory effect of protein derived from Tenebrio molitor larvae. J Life Sci, 29, 854-860 (2019)

Smith PK, Krohn RI, Hermanson GT, Mallia AK, Gartner FH, Provenzano MD, Fujimoto EK, Goeke NM, Olson BJ, Klenk DC. Measurement of protein using bicinchoninic acid. Anal Biochem, 150, 76-85 (1985)

Song PS, Chichester CO, Stadtman FH. Kinetic behavior and mechanism of inhibition in the Maillard reaction. I . Kinetic behavior of the reaction between D-glucose and glycine. J Food Sci, 31, 906-913 (1966)

Wang M, Hettiarachchy NS, Qi M, Burks W, Siebenmorgen
T. Preparation and functional properties of rice bran protein isolate. J Agric Food Chem, 47, 411-416 (1999)

Yamamoto H, Ogawa T. Antimicrobial activity of perilla seed polyphenols against oral pathogenic bacteria. Biosci Biotechnol Biochem, 66, 921-924 (2002)

Zhang B, Cui Y, Yin G, Li X, Zhou X. Alkaline extraction method of cottonseed protein isolate. Mod Appl Sci, 3, 77-82 (2009)

Zhang T, Li Y, Miao M, Jiang B. Purification and characterisation of a new antioxidant peptide from chickpea (Cicer arietium L.) protein hydrolysates. Food Chem, 128, 28-33 (2011)

Zhu J, Fu Q. Optimization of ultrasound-assisted extraction process of perilla seed meal proteins. Food Sci Biotechnol, 21, 1701-1706 (2012) 